\title{
Nonteratoid Medulloepithelioma Presenting in a 78-Year-Old Male
}

\author{
Christopher K.H. Burris $^{\text {a }}$ Vasilios P. Papastefanou ${ }^{b, c}$ Caroline Thaung ${ }^{d}$ \\ Gordon Hay ${ }^{b}$ Marianne Grantham ${ }^{e}$ Victoria M.L. Cohen ${ }^{b, c}$ \\ ${ }^{a}$ Department of Ophthalmology, University of Wisconsin-Madison, Madison, Wis., USA; ${ }^{b}$ Department of Ocular \\ Oncology, St. Bartholomew's Hospital, ' Department of Ocular Oncology, Moorfields Eye Hospital, d Department of \\ Eye Pathology, UCL Institute of Ophthalmology, and ' Department of Molecular Medicine, Royal London Hospital, \\ London, UK
}

\section{Key Words}

Genetics · Intraocular medulloepithelioma $\cdot$ Tumor

\begin{abstract}
Background: Medulloepithelioma is a rare congenital neoplasm derived from precursors of the nonpigmented ciliary epithelium of the ciliary body. The average patient age at clinical presentation is 3.8 years. Case Presentation: We present the case of a 78-year-old male with progressive lens subluxation and ocular hypertension who was found to have a ciliary body mass. After enucleation for presumed ciliary body melanoma, histopathology showed a nonteratoid medulloepithelioma. Cytogenetic analysis revealed abnormalities in chromosomes 3 and 8. Conclusion: Medulloepithelioma is often initially misdiagnosed. Though congenital in nature, it can exhibit rapid growth, have chromosomal abnormalities, and must be considered in all age groups.

(C) 2016 S. Karger AG, Basel
\end{abstract}

\section{Introduction}

Medulloepithelioma is an extremely rare congenital neoplasm, which most often involves the ciliary body. First described by Frederick Verhoeff in 1904 as a 'teratoneuroma', later by Ernst Fuchs as a 'diktyoma', it was not until 1931 that Roy Richard Grinker created the term 'medulloepithelioma' [1-3]. These tumors are believed to originate from the primitive medullary epithelium intended to form the nonpigmented ciliary epithelium of the ciliary body [4]. Due to their rarity, most of the literature on medulloepitheliomas consists of case reports or short case series. In the largest series, Broughton and Zimmerman [5] found 3.8 years to be the average age of patients at the time of clinical manifestation, and 5 years to be the median age at the time of surgery and histological diagnosis. We present an atypical case of this congenital neoplasm becoming symptomatic in an elderly adult.

\section{Case Presentation}

A 78-year-old retired male returned regularly to his optician for progressive changes in refraction in the left eye over 6 months, along with left eye pain for 1 month. The optician noticed a mass in the superior iris of the left eye, and referred him urgently for

\section{KARGER}

E-Mail karger@karger.com www.karger.com/oop
(2) 2016 S. Karger AG, Base

$2296-4681 / 16 / 0024-0218 \$ 39.50 / 0$
Victoria M.L. Cohen, MA, MB BChir, FRCOphth

Department of Ophthalmology, St. Bartholomew's Hospital, Moorfields Eye Hospital West Smithfield, London EC1A 7BE (UK)

E-Mail victoria.lendrum@googlemail.com 
Fig. 1. a Slit-lamp photograph of a retroiridal mass with iris thinning and lens subluxation. b B-scan ultrasound of a well-circumscribed heterogeneous mass measuring 5.6 (height) $\times 7.9 \mathrm{~mm}$ (base).

Fig. 2. a Pale, gelatinous nodule measuring $12 \times 8 \mathrm{~mm}$ in size. Hematoxylin and eosin. $\times 1$. b Neuroepithelial cells forming cords, trabeculae, and rosette-like structures (arrow) reminiscent of primitive neural tube. Hematoxylin and eosin. $\times 10$. c FISH analysis of the punch biopsy shows trisomy of chromosome 3 and the normal diploid chromosome 8 . Red probe: D3Z1, centromere 3; green probe: D8Z2, centromere 8. d FISH analysis of the FNA biopsy shows trisomy of chromosome 3 and occasional trisomy of chromosome 8 . Red probe: $\mathrm{D} 3 \mathrm{Z1}$, centromere 3; green probe: D8Z2, centromere $8 . \mathrm{CB}=$ Ciliary body.
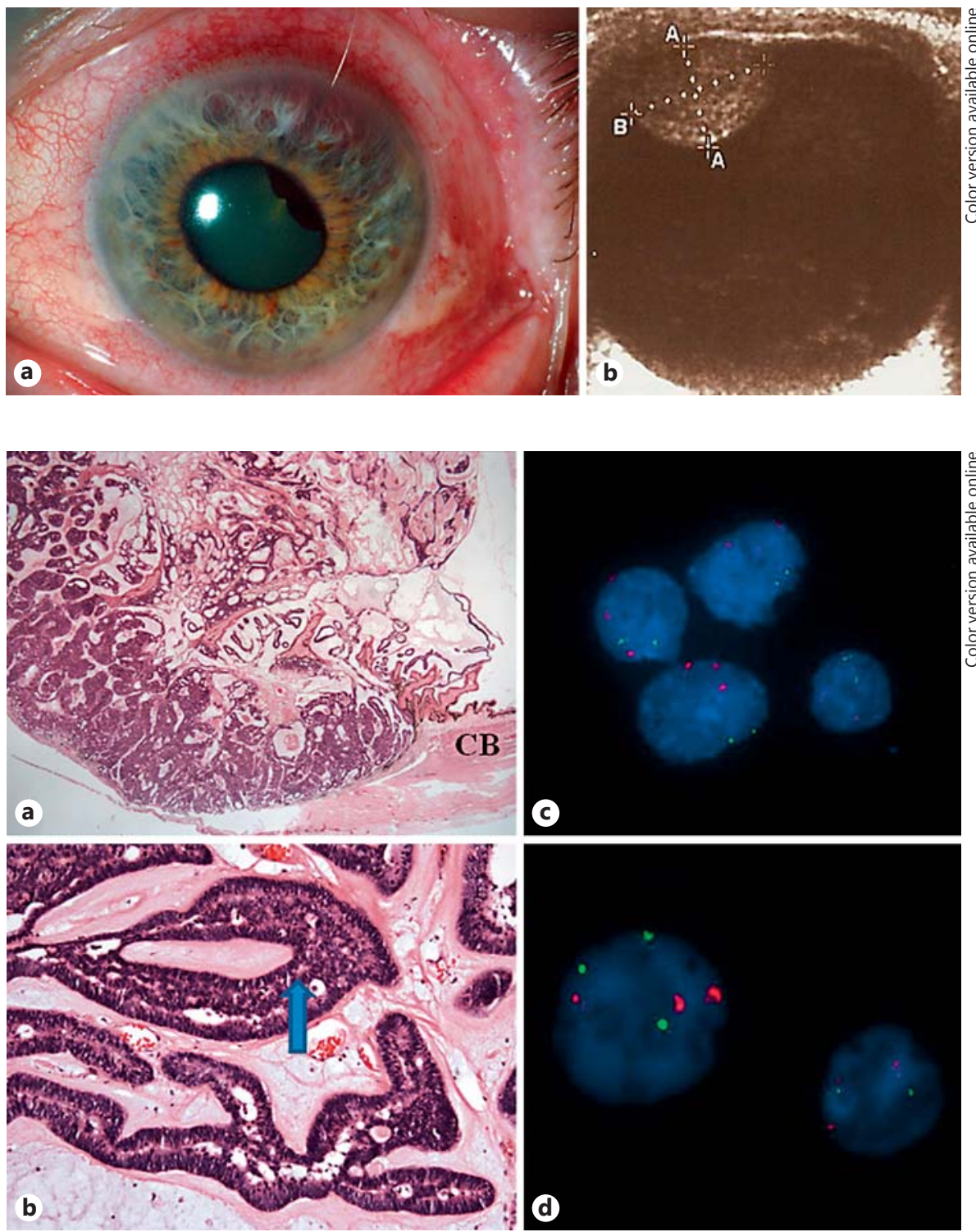

ophthalmic examination. On examination, visual acuity was $20 / 30$ in the OD and 20/80 in the OS. A pigmented, vascularized, bulbous mass was seen in the 11:00-2:00 position of the left iris with hemorrhage into the iris stroma (fig. 1a). B-scan ultrasound showed a mass with heterogeneous reflectivity causing lens subluxation (fig. 1b). Intraocular pressure measured $26 \mathrm{~mm} \mathrm{Hg}$ in the left eye, but the trabecular meshwork was open on gonioscopy. The patient was given the clinical diagnosis of ciliary body melanoma. Due to the presumed diagnosis as well as the patient's increasing pain and intraocular pressure, he was prescribed $0.1 \%$ dexamethasone eye drops 4 times daily, $1 \%$ cyclopentolate twice daily, slow-release acetazolamide $250 \mathrm{mg}$ by mouth once daily, and was referred to the Ocular Oncology Service of the St. Bartholomew's Hospital (London, UK). Various treatment options were discussed, including observation, but the patient opted for enucleation. The postoperative course was uneventful. Punch biopsy using a corneal tre- phine as well as fine needle aspiration (FNA) biopsies of the mass were obtained and sent for cytogenetic testing for chromosomes 3 and 8 (prognostic markers in uveal melanoma routinely tested at our center) [6]. The remainder of the specimen was preserved in $10 \%$ formalin and submitted for histological processing.

\section{Pathology}

Macroscopic examination showed a pale grey translucent gelatinous nodule in the ciliary body measuring $12 \times 8 \mathrm{~mm}$ in size.

Microscopic examination revealed a mass arising from the anterior ciliary body epithelium, consisting of neuroepithelial cells forming cords, trabeculae and rosette-like structures reminiscent of primitive neural tube (fig. 2a, b). Part of the mass was adherent 
to the posterior iris. Normal mitoses were seen. The copious background stroma was made up of Alcian blue-positive, hyaluronidase-sensitive material. Immunohistochemistry showed weak diffuse positivity for chromogranin but was negative for synaptophysin staining. S100 showed patchy strong positivity. The remaining immunohistochemistry for AE1/AE3, CAM5.2, CK7, CK20, and EMA demonstrated focal positivity.

Interphase fluorescence in situ hybridization (FISH) analysis was carried out using IGH/MYC, CEP8 tri-color dual fusion probe, CEP3 (D3Z1) SpectrumOrange probe, and CEP8 (D8Z2) SpectrumGreen probe (Abbott Molecular, Des Plaines, Ill., USA). FISH analysis of the punch biopsy showed an extra copy of the chromosome 3 centromere, indicative of trisomy 3 in 50 of 100 cells examined and the normal diploid component of the chromosome 8 centromere in 100 of 100 cells (fig. 2c). Interphase FISH analysis of the fine needle aspiration biopsy showed an extra copy of the chromosome 3 centromere, indicative of trisomy 3 , and an extra copy of chromosome 8 centromere and MYC (8q24), indicative of trisomy 8 in 38 and 34 of 100 examined cells, respectively (fig. 2d).

\section{Discussion}

These histological findings are consistent with a nonteratoid medulloepithelioma. Though experimental tumors have been created from ciliary body stem cells, in general, the term medulloepithelioma is reserved for embryonic neoplasms believed to arise from embryonal or fetal tissues, making 'embryonal medulloepithelioma' redundant and 'adult medulloepithelioma' contradictory [5-7]. At least 16 cases of medulloepithelioma have been reported in patients older than 20 years, with the oldest in a 79-year-old man $[9,10]$. We documented another male whose congenital tumor became symptomatic in his 7 th decade of life. Thus far, it has not behaved in an overtly aggressive or malignant manner (local invasion, metastasis, etc.). This is the first time that cytogenetic testing has been performed on an intraocular medulloepithelioma in an elderly adult.

The cytogenetics of medulloepithelioma are only recently beginning to be elucidated, with many genetic alterations including abnormalities in chromosomes 1, 4, 6, 8,15 , and 16 [11-13]. In two large series, Korshunov et al. [13] have recently proved that intraocular medulloepitheliomas and embryonal tumors of the central nervous system with multilayered rosettes are distinct nosologic entities, and Sahm et al. [14] found a high prevalence of DICER1 and KMT2D somatic mutations. Both the punch and FNA biopsies of our tumor showed trisomy of chromosome 3, which was rare in those series. All cells in the punch biopsy showed the normal diploid component of the chromosome 8 centromere and MYC (8q24), but some of the cells in our FNA biopsy contained trisomy of chromosome 8. Gain of chromosome 8 was common in those series. Intratumor genetic heterogeneity has not been previously documented in medulloepithelioma.

Medulloepithelioma of the ciliary body has been primarily diagnosed by FNA biopsy and cytology on two occasions. One was a pediatric case (8 years of age), which could not be conclusively differentiated from retinoblastoma, and the other was a 23-year-old case, who required a secondary tissue biopsy for a definitive diagnosis $[14,15]$. Besides the inconsistencies in diagnosis, FNA and tissue biopsy of malignancies carry a risk of systemic dissemination. Though systemic chemotherapy with a combination of vincristine, carboplatin, and etoposide has been successful in treating an aggressive medulloepithelioma with extraocular extension and metastasis, there is no standardized treatment regimen and the chemosensitivity in this case cannot be generalized to all types of medulloepithelioma $[16,17]$. Plaque brachytherapy has shown promise in inducing tumor regression in a small British case series of pediatric medulloepithelioma and in an adult case reported by Poon et al. [18]. In atypical presentations, primary enucleation remains a useful diagnostic and therapeutic tool, and should be considered in these cases. In conclusion, intraocular medulloepitheliomas are often initially misdiagnosed. Though commonly believed to be congenital, they may exhibit rapid growth, contain chromosomal abnormalities, and must be considered in all age groups.

\section{Statement of Ethics}

This study has been approved by our institute's committee on human research and conforms to institutional standards. No identifiable patient information was used.

\section{Disclosure Statement}

None of the authors has any propriety interests, financial competing interests, or conflicts of interest related to this submission.

\section{References}

1 Verhoeff $\mathrm{FH}$ : A rare tumor arising from the pars ciliaris retinae (terato-neuroma) of a nature hitherto unrecognized, and its relation to the so-called glioma-retinae. Trans Am Ophthalmol Soc 1904;10:351-377.

2 Fuchs E: Wucherungen und Geschwulste des Ciliarepithels. Albrecht Von Graefes Arch Ophthalmol 1908;68:534-587.

3 Grinker RR: Gliomas of the retina, including the results of studies with silver impregnations. Arch Ophthalmol 1931;5:920-935. 
4 Zimmerman LE: Verhoeff's 'terato-neuroma'. A critical reappraisal in light of new observations and current concepts of embryonic tumors. The Fourth Frederick H. Verhoeff Lecture. Am J Ophthalmol 1971;72:10391057.

5 Broughton WL, Zimmerman LE: A clinicopathologic study of 56 cases of intraocular medulloepitheliomas. Am J Ophthalmol 1978; $85: 407-418$.

6 Sisley K, Rennie IG, Parsons MA, Jacques R, Hammond DW, Bell SM, Potter AM, Rees RC: Abnormalities of chromosomes 3 and 8 in posterior uveal melanoma correlate with prognosis. Genes Chromosomes Cancer 1997;19:22-28.

$7 \mathrm{Ni}$ A, Wu MJ, Chavala SH: Sphere formation permits Oct4 reprogramming of ciliary body epithelial cells into induced pluripotent stem cells. Stem Cells Dev 2014;23:3065-3071.

8 Willis RA: The embryonic tumors and teratomas; in The Borderland of Embryology and Pathology, ed 2. London, Butterworth, 1962, pp 422-466.

9 Sosińska-Mielcarek K, Senkus-Konefka E, Jaskiewicz K, Kordek R, Jassem J: Intraocular malignant teratoid medulloepithelioma in an adult: clinicopathological case report and review of the literature. Acta Ophthalmol Scand 2006;84:259-262.

10 Floyd BB, Minckler DS, Valentin L: Intraocular medulloepithelioma in a 79-year-old man Ophthalmology 1982;89:1088-1094.

11 Betts DR, Leibundgut KE, Niggli FK: Cytogenetic analysis in a case of intraocular medulloepithelioma. Cancer Genet Cytogenet 1996; 92:144-146.

12 Sahm F, Jakobiec FA, Meyer J, Schrimpf D, Eberhart CG, Hovestadt V, Capper D, Lambo S, Ryzhova M, Schüller U, Zheludkova O, Kumirova E, Lichter P, von Deimling A, Jones DT, Pfister SM, Kool M, Korshunov A: Somatic mutations of DICER1 and KMT2D are frequent in intraocular medulloepitheliomas. Genes Chromosomes Cancer 2016;55:418427.

13 Korshunov A, Jakobiec FA, Eberhart CG, Hovestadt V, Capper D, Jones DT, Sturm D, Stagner AM, Edward DP, Eagle RC, Proia AD, Koch A, Ryzhova M, Ektova A, Schüller U, Zheludkova O, Lichter P, von Deimling A, Pfister SM, Kool M: Comparative inte- grated molecular analysis of intraocular medulloepitheliomas and central nervous system embryonal tumors with multilayered rosettes confirms that they are distinct nosologic entities. Neuropathology 2015;35: 538-544.

14 Babu N, Dey P: Medulloepithelioma of ciliary body diagnosed by fine needle aspiration cytology. Cytopathology 2003;14:93-94.

15 Davidorf FH, Craig E, Birnbaum L, Wakely P Jr: Management of medulloepithelioma of the ciliary body with brachytherapy. Am J Ophthalmol 2002;133:841-843.

16 Gupta A, Khetan V: Chemosensitivity of medulloepithelioma. Ophthalmology 2011;118: 1488.

17 Meel R, Chawla B, Mohanti BK, Kashyap S, Bakhshi S: Ocular medulloepithelioma chemosensitivity. Ophthalmology 2010;117: 2440.e1-e2.

18 Poon DS, Reich E, Smith VM, Kingston J, Reddy MA, Hungerford JL, Sagoo MS: Ruthenium-106 plaque brachytherapy in the primary management of ocular medulloepithelioma. Ophthalmology 2015;122:19491951. 